\title{
THE WORK OF LABOR BOARDS AND AGENCIES IN WARTIME
}

\author{
CARL R. SchEdLER*
}

The description in this article of the activities arising out of the war effort of the governmental agencies which deal with industrial disputes and economic problems must of necessity be factual and uncolored by psychological points of view or personal reference. The subject is complex and little understood. To attempt to simplify the treatment or create an apparent logic for the development would be a distortion of facts. I present a candid snapshot of the agencies administering these activities with no attempt to make them seem picturesque or unique.

With the exception of the United States Conciliation Service, the National Labor Relations Board, the National Mediation Board, and the National Railroad Adjustment Board, all the agencies presented have grown up in the atmosphere of wartime emergency. Although new in point of time, they are very largely traditional in their developments and procedures. What they lack in color is compensated to a considerable degree by the significance of their work. Their future is unpredictable but I dare say the nature of the business they conduct is of lasting importance to the nation. This may give them a lease on life beyond the duration of the war.

\section{The United States Conciliation Service}

The job of settling labor-management disputes in our present war effort is not a new function of the United States Conciliation Service. Since I9r3 it has been continuously settling all types of labor-management disputes in almost all industries throughout the country and outlying possessions. The present war, of course, presents many new problems. To meet these and to aid continuous and increased production, various new programs and policies have been adopted.

In the President's Executive Order of January 12, 1942, ${ }^{1}$ the Conciliation Service was named the first-line agency for handling labor-management disputes affecting the war production effort. Although this order did not set forth new functions for the Service, it was especially significant because only a month before labor and management had promised to settle all grievances through existing mediation and arbitration machinery.

* B.S., x927, Oklahoma Agric. \& Mech. College; LL.B., 1932, Georgetown University. Assistant Director, United States Conciliation Service, United States Department of Labor. Formerly Associate Solicitor, United States Department of Labor.

if FED REG. 237. 
The first and most noticeable reaction to the Executive Order was an increase of cases brought to the attention of the Service at an early stage of the dispute. A year before, the Service was carrying an active case load of about 600 cases. Five months after the new emphasis on mediation and conciliation, the Service had over I600 active cases. Of these 1600 cases, a very small percentage involved strikes affecting the war effort. In fact, the reports from day to day over a period of months show that less than 7 hundredths of one percent of the cases were strikes which hindered the war production program.

From the beginning of the defense program, the Service had placed primary emphasis on all cases affecting production. With the declaration of war and a growing case load, it became increasingly necessary to give priority, and in some instances special treatment, to all cases which affected the production and transportation of materials vital to the war effort.

The special treatment of cases affecting the war effort has largely consisted of an increased use of voluntary arbitration, conciliation by panels of Commissioners, and the certification of cases to the National War Labor Board. These methods, in addition to regular conciliation procedures, have enabled the Service to settle all but a limited number of cases. In fact, for the first eight months of 1942 , the Service settled almost six thousand cases while it was necessary to certify only 436 cases to the War Labor Board for further action. ${ }^{2}$

\section{The National Labor Relations Board}

The National Labor Relations Board ${ }^{3}$ has been operating continuously and successfully for six years. Its jurisdiction has been upheld by the Supreme Court. Its procedure has been approved, and the Board is now a well-established agency. Although it has been given no new duties in our present war effort, the Board has a primary function in administering the Act which insures the right of workers to bargain collectively.

Recent reports from the Board show that four out of five workers in Board cases are employed in war industries; the incoming case load of the Board exceeds one thousand cases a month; and the Board gives priority to all cases affecting the war effort. There is also evidence of an increased desire of workers to determine for themselves their bargaining representatives. This has shifted the normal predominance of cases before the Board from cases containing charges of unfair labor practices by employers to cases of petitions for employee elections.

\section{The National Mediation Board}

The National Mediation Board was created in $1934^{4}$ to govern the labor relations of interstate railroads and airlines and their employees. It has power to mediate all

\footnotetext{
${ }^{2}$ For a more extended description of the work of the Service, see Steelman, The Work of the United States Conciliation Service in War Time Labor Disputes, infra, p. 462. ED.

${ }^{8}$ Established by the National Labor Relations Act of July 5, 1935, 49 STAT. 451, 29 U. S. C. $\$ \times 53$.

- Act of June 21, 1934, 48 STAT. 1193, 45 U. S. C. \$154.
} 
disputes concerning the establishment of, or change in, the agreements covering rates of pay, rules, and working conditions in these industries after direct negotiation of the parties has been attempted. A party wishing to make a change in an agreement must give 30 days' written notice to the other party and, within Io days of its receipt, the time and place for joint conference must be arranged. If agreement is not reached, either or both parties may request the assistance of the National Mediation Board or the Board may intervene of its own accord. The Board's sole function, however, is one of conciliation. If the case is not settled by mediation and a strike vote is taken, the Board may notify the President who then appoints a factfinding body. The findings of this body are enforced only by public opinion.

Now that labor and management have pledged "no strikes or lockouts" for the duration, it would be contrary to the effective prosecution of the war for a strike vote to be taken. In order that investigations of cases can be made without a strike vote, the President on May 22, I942, created the National Railway Labor Panel ${ }^{5}$ to which the National Mediation Board can certify cases for investigation and report to the President. This executive order is of vital importance to the war effort as the Board has been dealing almost wholly with cases affecting war transportation.

\section{The National Railway Labor Panel}

The National Railway Labor Panel created by the Executive Order of May 22, I942, ${ }^{6}$ was authorized to handle railway labor disputes which are not adjusted by the National Mediation Board. The Board notifies the Chairman of the Panel concerning the unsettled dispute and, if he decides that it may interfere with the prosecution of the war, he will select three members from the panel of nine to serve as an emergency board to investigate the dispute and report to the President. This board has final jurisdiction over the dispute and will make every effort to settle it.

\section{The National Railroad Adjustment Board}

The National Railroad Adjustment Board was established under the Railway Labor Act of $1934^{7}$ for the adjudication of disputes involving the interpretation or application of agreements covering pay, rules, and working conditions on the railroads. The Board consisting of thirty-six members, eighteen selected by the carriers and eighteen selected by organizations of railroad employees, is similar to an arbitration tribunal. It hands down decisions which are binding upon both parties. A comparable board for airlines, the National Air Transportation Adjustment Board, ${ }^{8}$ may be set up by the National Mediation Board when circumstances require.

\section{The National Defense Mediation Board}

The National Defense Mediation Board was created by the Presidential Executive Order of March 19, I941, ${ }^{\circ}$ and operated until abolished on January 12, 1942 by the

\footnotetext{
$\checkmark$ Exec. Order No. 9172, 7 FED. REg. $3912 . \quad{ }^{\circ} I b i d$.

${ }^{7}$ Act of June 21, I934, 48 STAT. Ir 89,45 U. S. C. $\$ 153$.

${ }^{B}$ Act of April 10, 1936, 49 STAT. Ixgo, 45 U. S. C. $\$ 185$.

- Exce. Order No. 8716, 6 FEd. Reg. 1532.
} 
Executive Order creating the National War Labor Board. The former board was composed of eleven members appointed by the President: three representing the public; four representing the employees; and four representing the employers. The Order was later amended to provide for alternates. ${ }^{10}$

The Board was authorized to act "whenever the Secretary of Labor certifies to the Board that any controversy or dispute has arisen between any employer and any employees" which threatens to obstruct production or transportation essential to national defense and which has not been adjusted by the Conciliation Service. To facilitate certification, the Secretary of Labor designated a three-man committee to advise as to the most effective time for certification. This committee was composed of the Chairman of the National Defense Mediation Board, a representative of the OPM, and the Director of the Conciliation Service.

Upon certification of a case by the Secretary of Labor, the Board was authorized to continue negotiation, afford means of voluntary arbitration, conduct investigations, hold hearings, take testimony, make public findings of fact and make formal recommendations. Under the terms of the Executive Order, controversies certified to the Board were to be handled by a panel of three Board members, or alternates, with labor-management and the public represented on each panel.

The establishment of this Board in no way implied compulsion. The Board asked the parties to do specified things and made formal recommendations. The expectation was that these recommendations would be accepted because the Board had the support of the President and the public.

During the ten months of the Board's existence, many controversial issues arose. Of these, union status was the most difficult issue, according to a statement by the Chairman of the Board. In fact, the Board has stated that it was the recommendation of a maintenance-of-membership clause in the Kearny Shipyard case, and the refusal to grant a union shop in the captive coal mine dispute which ended the influence of the Board. During its life II4 cases were certified to the Board. Twenty-three of these were turned over to the National War Labor Board upon its establishment.

\section{National War Labor Board}

The President issued the Executive Order of January 12, $1942^{11}$ to establish a definite policy for the settlement of labor-management disputes as well as to provide further mediation machinery. As has been pointed out, this Order created the National War Labor Board to replace the National Defense Mediation Board. It set forth three steps for adjusting and settling labor-management disputes "which might interrupt work which contributes to the effective prosecution of the war": first, direct negotiations by the parties involved; second, conciliation by the United States Conciliation Service; third, mediation or arbitration by the National War Labor Board.

The Board is composed of twelve members, four each to represent the public, the employers, and the employees. The Order also provided for alternates and for a Chairman and Vice-Chairman chosen by the President.

${ }^{10} \mathrm{Id}$. at 1809 .

${ }^{12}$ Exec. Order No. 9017, 7 FEd. REg. 237. 
The Board is authorized to act when the Secretary of Labor certifies a dispute "which might interrupt work which contributes to the effective prosecution of the war" and which has not been promptly settled by the Conciliation Service. The Executive Order also states that "the Board at its own discretion after consultation with the Secretary may take jurisdiction of a dispute on its own motion." This it has done only once. Its practice is to handle only cases certified after settlement has been attempted by the Conciliation Service.

When the Board enters the case it is authorized, as was its predecessor, to continue negotiations, afford means of voluntary arbitration, conduct investigations, hold hearings, take testimony, make public findings of fact, and make formal recommendations.

The Board's first action on a new case is usually to assign it to mediation. ${ }^{12}$ The mediator assigned attempts to settle the case or to narrow the issues. The next step is to have the parties appear before a mediation panel of the Board, composed of one representative of the public, one of management, and one of labor. If the issues in a case are not resolved by mediation, voluntary arbitration is then suggested. If either party refuses arbitration, the dispute comes before the twelve-man War Labor Board for a final decision. The mediation panel draws up its recommendations for settlement and is unanimous in its conclusions. In practically every case, the Board has adopted the panel recommendations, but, in case of disagreement or desire for further information, the Board holds a public hearing and the parties present arguments for and against the panel recommendation. The Board determination is final and there is no appeal from the Board's order.

From its inception, the Board has faced two main issues: union security and wages. ${ }^{13}$ At the President's labor-industry conference, out of which the Board grew, union security was the one acute difference. The industry members of the conference were opposed to having cases involving this issue settled by a Board created by the President. The Board's power, however, was not limited and soon after its creation it passed the following resolution: ${ }^{14}$

This Board has authority to consider all labor disputes which might interrupt work which contributes to the effective prosecution of the war, including labor disputes as to union status.

From the establishment of the Board on January I2, until September I, a total of 460 cases came before the Board. Twenty-three of these were cases carried over from the National Defense Mediation Board while the other 437 were new cases. Of these, 205 were disposed of by September I; 66 through mediation, 16 with voluntary arbitration, and 100 by Board decisions, and $2 \mathrm{I}$ through other dispositions.

The Board has given several evidences that it intends to have its recommendations

${ }^{12}$ A more detailed discussion of the Board's procedure is presented in the last article in this symposium. ED.

${ }^{23}$ For a discussion of the Board's rulings on these issues, see Rice, The Latv of the National War Labor Board, infra, p. 470 . ED.

'Tesolutions of March 18, I942, 10 LAB. REL. REP. I13. 
accepted and that it knows how this can be done. One such example was a recent case in which the Board conducted a public hearing for the purpose of receiving testimony on a company's declaration that it would not comply with a Board order. At the hearing, the Board stated that compliance with its orders was expected as a patriotic duty and that defiance of such orders was tantamount to defiance of the President of the United States. The company complied with the order. ${ }^{15}$

\section{Building Trades Stabilization Board of Review}

When in July, 194I, representatives of the Building and Construction Trades Department of the AFL and representatives of certain governmental agencies engaged in defense construction met together under the auspices of OPM, they voluntarily entered into an agreement ${ }^{16}$ to stabilize certain working conditions. The agreement applied only to defense construction. It established uniform overtime rates and uniform shifts; pledged continuous production; created a Board of Review; contained specific provisions relating to sub-contractors and apprentices; and provided for predetermination of wages and for the application of the agreement.

The Board of Review, consisting of representatives of government agencies and of the AFL Building and Construction Trades Department, is empowered to interpret the agreement under which it operates and adjusts the disputes arising under it. In case a dispute involves a specific governmental agency, that agency may designate a representative as a temporary member of the Board for the mediation of that dispute.

The stabilization agreement provided that: "The Board shall have no authority to encroach upon or to relieve any Governmental agency of its legal authorities or responsibilities." Other governmental agencies, therefore, continued to aid in maintaining harmonious labor-management relations in the building trades field.

The Board, according to its own statement, was not intended to provide a forum for hearing and determining all disputes growing out of the stabilization agreement between employers and employees in defense construction, but rather to function as a court of last resort for the adjudication of disputes after all other efforts on the part of the union and the governmental agency involved have been exhausted. The Board also reserves the right to decline to sit in judgment on any dispute which, in its opinion, is not related to the stabilization agreement or which involves parties not bound by the terms of the agreement.

Recently ${ }^{17}$ the Board ruled that it had no authority to designate collective bargaining agencies since the stabilization agreement does not provide for the union shop or other aspects of employee representation. The Board also determined that the agreement applies to contractors doing work for state housing authorities by reason of the fact that the Federal Housing Authority is a party to the agreement and finances in large part the state housing authorities.

When disputes are accepted by the Board for adjustment, the parties to the dispute must file a joint submission stating the issues involved. They must then file with the

${ }^{15}$ As to Presidential action in case of non-compliance see Rice, supra note 13 , at 488,489 . Ev.

10 (I94I) 8 LAB. REL. REP. 764.

${ }^{17}$ See (1942) ro LAB. REL. REP. 191. 
Board and with other disputants a statement of claims containing all the facts tending to support the contention of the disputant presenting the statement. At the hearings, there can be only one spokesman for each side and oral arguments are permitted only on points contained in the written statement. The decision of the Board in writing is final and binding.

\section{Building Trades Wage Adjustment Board}

The Building Trades Unions of the AFL and the various contracting agencies of the Government voluntarily agreed on May 22, $1942,{ }^{18}$ to stabilize wages for the duration of the war. Those governmental agencies signing the agreement were the War and Navy Departments, Federal Works Administration, National Housing Administration, Reconstruction Finance Corporation, and the Maritime Commission.

The agreement provides for the inclusion of all war construction work, in the continental United States, which is done for or financed by the Government except non-federal construction where state laws govern wage rates. Arrangement was made for the stabilization of wages on July $\mathrm{I}, \mathrm{x} 942$. This provision will be subject to revision only in cases where rates are inadequate because of some abnormal change in conditions or where rates were set at a time so long before July I, r942, as to be out of line with the general prevailing wages. The agreement also provided for a Wage Adjustment Board to determine when adjustments should be made and the amount of the adjustment.

The Wage Adjustment Board is set up in the Department of Labor and consists of a chairman to be appointed from the Department, three representatives of the contracting agencies of the Government, and three representatives of labor from the building construction industry.

The Board has power to make the necessary rules of procedure, to investigate, and to recommend adjustments of wage rates under the provisions of the agreement. It may also request the Solicitor of the Department of Labor to conduct investigations, hold hearings, and make reports to the Board on the prevailing rate of wages for any or all classes of laborers and mechanics in the building construction industry in any locality; or the relation of such wage rates to those generally prevailing in the industry, trade or locality; or on the relation of such wages to the cost of living.

Requests for wage adjustments are considered by the Board if they are presented by local labor organizations with the approval of the national or international labor organization and with the approval of the Building Trades Department of the AFL.

\section{The Ship Stabilization Committee}

The number of ships needed to carry out the defense and war programs made it necessary to produce ships of all varieties more rapidly and in far greater numbers than had previously been conceived. Cargo ships and battleships were needed as

\footnotetext{
${ }^{18}$ See (1942) 10 LAB. REI. REP. 442.
} 
were tankers, tugs, barges, airplane carriers, transports, torpedo boats, and many other varieties.

To meet the goals of unprecedented proportions it was necessary for labor and management, as well as the Government as buyer, to solve jointly and in a voluntary way some of the common problems to be faced on the Atlantic and Pacific Coasts, the Gulf and Great Lakes. To meet this need, the Ship Stabilization Committee was established on November 27, 1940. ${ }^{19}$ This Committee consists of two representatives from the AFL, two from the CIO, three from management, and three from the Government. The latter includes the Chairman who is a representative of the WPB (originally of the National Defense Advisory Commission) and one representative each from the Navy Department and the Maritime Commission.

The function of this committee, as stated by the Defense Advisory Committee of the former National Defense Commission under which the Committee originally operated, is to develop a labor program which will insure the most efficient and speedy construction of ships. The Committee is also instructed to make a detailed investigation of wage rates and working conditions with particular reference to the migration of workers from yard to yard and the effect upon production.

Soon after the Committee was formed, it adopted a policy resolution which has aided continuous production and harmonious labor-management relations in the industry.

The Ship Stabilization Committee . . . adopts a policy urging that there should be no interruption of production on the part of shipyard employers and of shipyard employees before all facilities at the disposal of the National Defense Advisory Commission for adjusting differences have been exhausted.

The Committee was soon able to list the issues which would undoubtedly arise in attempting to stabilize the industry and to formulate policy to meet these issues. It was decided that a standard basic hourly rate for skilled mechanics would be arrived at through voluntary negotiations and would be subject to periodic review. The definitions of occupations and rates for other types of work would be worked out in local collective bargaining negotiations because of the variety of local situations. It was determined that overtime which would protect labor standards and yet not hinder any necessary lengthening of the work week would be a matter for consideration. Sufficient grievance machinery to meet all problems, with provision for arbitration when necessary, would be considered. After these points were determined, the Committee decided it would then attempt to agree to a program of no strikes or lockouts during the emergency. Many other problems such as shift premiums and training of workers were also discussed and broad policy formed.

The Committee then set about to bring stabilization to the industry through the voluntary cooperation of the parties of the four areas or zones-the Atlantic and the Pacific Coasts, the Gulf, and Great Lakes. The first of the conferences to establish

${ }^{10}$ (1940) 7 LAB. REL. ReP. 371. 
zone standards was the Pacific conference which met in February, 1941. ${ }^{20}$ This was followed in the next few months by the Atlantic, Great Lakes, and Gulf conferences. Through a gradual and voluntary process of negotiation, with representatives of labor, management, and the Government participating and with the Government actually party to the agreement, satisfactory zone standards were reached.

As the conferences progressed, variations to the established policies were developed. On the Pacific Coast three agreements were formed: ${ }^{21}$ the Zone Standards Agreement covering wages, shifts, overtime, and the settlement of grievances in ship construction only; the Repair and Conversion Agreement; and the Master Agreement covering further working conditions. In the conferences in the other three areas, only one agreement was entered into to cover each area. These agreements ${ }^{22}$ covered ship repair as well as construction. They also provided for more details as it was found easier to translate such a program into local agreements. Originally it had been decided that the labor organization which had the majority of workers under agreement in each zone was to represent labor-with the minority conforming to the approved standards. So many gradual changes had been made as the various conferences progressed, that when the fourth conference, the Gulf States conference, was held, both labor organizations were actively represented.

All four agreements provided the following: a basic hourly wage for skilled mechanics ( $\$ 1.13$ in three conferences and $\$ 1.07$ in the Gulf); time and a half over 8 hours a day and 40 hours per week; double time for Sundays and holidays; premiums for the second and third shifts; settlement of grievances through negotiation, conciliation, and arbitration; and no strikes or lockouts for the duration.

In Chicago on April 27, I942, a year after the first stabilization agreements were ratified, a national conference of management, labor, and government representatives concerned with the shipbuilding industry was held under the auspices of the Shipbuilding Stabilization Committee. ${ }^{23}$ This conference was called to adjust and stabilize wages in view of the increased cost of living and to take into consideration a number of other important matters.

The President by telegram on May 4 urged the conference to stabilize wages so that the "wage standards of the workers in the shipbuilding industry and in other industries, and the living standards of all persons of modest income, may be preserved against the inflationary rise in the cost of living." These words played an outstanding part in the amendments adopted by the conference on May 16. ${ }^{24}$ Wage differentials were abolished as a standard wage rate of $\$ 1.20$ for skilled mechanics was set for all four zones. At the same time, the wage rates of all other employees increased by eight cents an hour except in the Gulf where the increase was slightly more in an attempt to standardize the whole industry. Overtime, holiday, and vaca-

\footnotetext{
${ }^{20}$ The Conference is reported in (194I) 7 LAB. REL. REP. 600.

Ibid.

82 For reports of these agreements, see (194I) $8 \mathrm{id} .585,732$.

${ }^{88}$ Sce (1942) Io LAB. REL. REP. 423. ${ }^{24}$ For full text, see ibid.
} 
tion provisions were modified. It was determined that any disputed point in the interpretation and application of the agreements or amendments should be referred to the Shipbuilding Stabilization Committee. It was also decided that the provisions decided upon should apply to the construction of new vessels and that separate zone conferences should decide upon the conditions to apply to repair and conversion.

Shortly following the Chicago conference, a conference ${ }^{25}$ on the Pacific Coast made an important change in the conditions applying to repair and conversion. It was determined that conversion work should be deemed constiuction work when on a "new vessel," a term applying to any newly constructed vessel prior to its completion, final acceptance, or actual employment in the service for which it has been constructed.

The stabilization agreement has now been in effect one year. It has covered an industry strefching up and down both coasts, on the Great Lakes and in the Gulf. It has included all types of plants with every variety of employee organization. And during the entire time there has been only one major dispute and that involved an internal union situation. This record gives evidence that the agreement was flexible enough to provide for the necessary settlement of disputes, the adjustment of rates, and inclusion of the desires of both labor organizations.

Because we have had stabilization, coordination, and cooperation of Government, labor, and management there have been harmonious labor-management relations which have made it possible for ships of all varieties to roll down the ways months ahead of schedule.

\section{Maritime War Emergency Board}

The Maritime War Emergency Board evolved as an outgrowth of the joint conference of labor and management representatives of the maritime industry. The President appointed the three-man Board on December $19,1941,{ }^{26}$ to aid in expediting and coordinating the industry's war effort.

The unions, representing the personnel of the vessels of the American merchant marine, and the operators of those vessels had pledged all-out and uninterrupted cooperation with the war effort. To meet this goal, it was necessary for all questions arising to be settled promptly and satisfactorily. Under normal conditions this would have been possible through regular collective bargaining procedure. However, because of war conditions, neither labor nor management was in a position to obtain information concerning the extent of war risks sufficient to enable them to bargain intelligently on questions relating to war risk compensation and insurance of personnel. The Board, therefore, was established to afford additional procedure for settling these questions on the basis of adequate and accurate government information.

Any question relating to war risk compensation or personnel insurance, not settled through ordinary channels, can be referred to the Board by either party upon

${ }^{20}$ For full text, see id. 503, 508.

${ }^{30} \operatorname{Sec}(1941) 9$ Las. ReL. Rep. 463. 
written notice to the Board and to the other party involved. After notice, the Board hears the evidence of both sides and then renders a decision in writing. All decisions are final and binding.

In attempting to meet the aims set for it by the joint labor-management maritime conference, the Board established insurance for all personnel of American merchant marine vessels; defined danger zones; set bonus rates for danger zones; made bonus rates retroactive to December 7; froze contracts; and provided for loss or damage to personal effects. ${ }^{27}$ It provided procedure for the settlement of disputes arising from new issues. In May, I942, the Board was working on the new problems of insurance to be paid dependents of seamen lost in the period December 7-22, and "creative insurance" to cover seamen lost through indirect war action. The Board has also provided for the settlement of disputes over the interpretation of its decisions.

\section{Labor Production Division of the War Production Board}

The Labor Production Division of the WPB, formerly the Labor Division of the OPM, was established as early as May, I940, when it was formed as a part of the National Advisory Defense Committee to aid the uninterrupted production of defense materials. It became an operating unit of the Office of Production Management on March 18, 1941. When the War Production Board was formed on January 16, 1942, it then became a part of that Board. And in April, 1942, the Labor Division became the Labor Production Division.

The Labor Division operated through various branches: labor morale, labor standards affecting the war effort, labor relations, and labor supply and training. When the War Manpower Commission was established by Executive Order, on April 18, 1942, ${ }^{28}$ however, the labor supply activities of the Division were taken over by the War Manpower Commission and the labor training activities by the Federal Security Agency.

The Labor Supply Branch was established to coordinate activities for recruiting, training, and maintaining qualified workers in industries vital to the defense and war effort. The Training-Within-Industry Branch was formed to advise and assist war industries in establishing programs of upgrading, apprenticeship, foreman training and on-the-job training. And these methods have been installed in over 3,000 war contracting concerns. The Defense Training Branch was set up to stimulate training programs conducted outside of the industry. The Labor Relations Branch was formed with a group of labor and management consultants who sought to spot labor problems and to aid in establishing harmonious labor-management relations. The Priorities Branch was created in an effort to check serious dislocations of labor due to shortages of materials and supplies. The Defense Housing Branch was established to survey the housing needs of localities handling war orders, and the Negro Employment and Training Branch sought to train and integrate Negro workers with the war industries.

\footnotetext{
${ }^{27}$ For reports on the Board's activities, see $i d .603,609 . \quad{ }^{28}$ 7 FED. REG. 29r9.
} 


\section{Committee on Fair Employment Practices}

The Committee on Fair Employment Practices was formed by a Presidential Executive Order issued June 25, r $94,{ }^{29}$ and operates as a working unit of the Labor Division of the WPB. The Order specifies that all contracts let by government agencies shall stipulate that the contractor will not discriminate in employment practices against any worker because of race, creed, color, or national origin. The Committee is composed of five members whose duty it is to receive and investigate complaints of discrimination in violation of the Order and to make recommendations to the President or the Government to effectuate the Order's provisions.

Through various studies and analysis, the Committee found evidences of discrimination in a number of plants handling government contracts. In some of these, investigations have been made and directive orders issued. These orders give the officials in charge of employment written instruction to comply fully with the President's Order and tell them to cease publication of help-wanted advertisements specifying "Gentile," "Protestant," or "white." These plants must also file with the Committee a monthly report showing the number and classification of new workers employed. Some orders also provided that the industries shall give written notice to all employment agencies with which the plant does business saying that they will accept application for all types of employment without discrimination as to race, color, creed, or national origin.

\section{The War Manpower Commission}

The War Manpower Commission was established by Executive Order on April I8, 1942,30 to formulate plans, policies, and legislative programs in order to assure the most effective mobilization and maximum utilization of the nation's manpower in the prosecution of the war. The Commission consists of the Federal Security Administrator as Chairman, and one representative from each of the following departments and agencies: the Departments of War, Navy, Labor, and Agriculture, the War Production Board, the WPB Labor Production Division, the Selective Service System, and the United States Civil Service Commission. These representatives are charged with estimating the manpower requirements for industry; reviewing the estimated needs for military, agricultural, and civilian manpower; and establishing policies for the necessary recruiting and training of workers to meet the needs. The Commission is also directed to collect, compile, and coordinate labor data of various federal departments and agencies.

The Executive Order creating the War Manpower Commission provided that ten existing agencies shall conform to the policies, directives, regulations, and standards prescribed by the Chairman. The Selective Service System was ordered to conform with respect to the use and classification of manpower needed for critical industrial, agricultural, and governmental employment; the United States Civil Service Commission with respect to the filling of positions in the Government

${ }^{20} 6$ FED. REG. 3 rog.

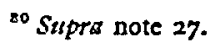


service; and the Department of Agriculture, with respect to farm labor statistics, farm labor camp programs, and other labor market activities. Activities of other agencies included were the Federal Security Agency's employment service and defense training functions; the Work Projects Administration's placement and training functions; the Railroad Retirement Board's reemployment service activities; the Office of Defense 'Transportation's labor supply and requirement activities; the Bureau of Labor Statistics of the Department of Labor; the Labor Production Division of the WPB; and the Civilian Conservation Corps.

Several agencies and functions were transferred to the Commission: the labor supply functions of the Labor Division of the WPB; the national roster of scientific and specialized personnel of the United States Civil Service Commission; and the Office of Procurement and Assignment in the Office of Defense Health and Welfare Services in the Office of Emergency Management. Several other agencies and functions were transferred to the Office of the Administrator of the Federal Security Agency by the Order creating the Commission. These were the apprenticeship section of the Division of Labor Standards of the Department of Labor and the training functions of the WPB's Labor Division.

The Chairman of the Commission announced that one or more directives would be issued to prevent piracy of workers in war industries. He indicated, however, that piracy of workers is only one aspect of the larger problem which the Commission must solve, namely, the most efficient use of the entire civilian manpower of the nation in prosecution of the war.

In carrying out this larger problem, the Chairman indicated that the United States Employment Service would probably be the initial mechanism. Under this arrangement, employment and transfers would be obtained through the Employment Service. "Under any of the plans now contemplated the restrictions will apply only to employers. There will be no restrictions placed upon the freedom of a worker to work where he chooses except that he must secure it through the Employment Service."

If an employer refuses to comply with methods for recruiting workers, the United States Employment Service will report this to the War Manpower Commission, the WPB, and the War and Navy Departments so that appropriate action can be taken.

If a worker refuses to accept suitable employment in a war industry without reasonable cause, the circumstances will be reported to the Selective Service System for consideration in connection with any request for deferment on occupational grounds. The Commission still has under advisement the methods by which the new policy can be enforced short of legislation.

These boards and agencies dealing with our labor-management relations in this time of war are doing a necessary job in a quiet way. They seldom command headlines, but they are attacking the difficult problems of human relations which must 
be solved in advance of victory days. They are providing the practical answers which are increasing our production and expediting the war effort. And, in the days to come, these agencies will stand as guideposts for future labor-management relations in an era that inevitably must rest largely upon the foundations of cooperation and mutual understanding.

\section{APPENDIX}

The name of the chief official and the address ${ }^{31}$ of each of the existing agencies discussed in this article is listed below.

Building Trades Stabilization Board of Review

Lewis K. Comstock, Chairman

Social Security Building

Fourth Street and Independence Avenue, S. W.

Bullding Trades Wage Adjustument Board

D. W. Tracy, Chairman

Department of Labor Building

I $4^{\text {th }}$ and Constitution

Committee on Fatr Emploument Practices

Lawrence Cramer, Chairman

Social Security Building

Fourth Street and Independence Avenue, S. W.

Labok Production Division of the War Production Board

Wendell Lund, Director

Social Security Building

Fourth Street and Independence Avenue, S. W.

Maritime War EMrrgency Board

Captain Edward Macauley, Chairman

Department of Commerce Building

I $4^{\text {th }}$ \& E Streets, N. W.

National Labor Relations Board

Harry A. Millis, Chairman

326 Shoreham Building

Fifteenth and $\mathrm{H}$ Streets, N. W.

National Mediation Board

David J. Lewis, Chairman

North Interior Building

F Street between Eighteenth and Nineteenth

National Railroad Adjustment Board

J. H. Sylvester, Chairman

220 South State Street

Chicago, Illinois

National Railway Labor Pangl

William M. Leiserson, Chairman

326 Shoreham Building

Fifteenth and H Streets, N. W.

${ }^{8 x}$ Except where otherwise noted, the address given is in Washington, D. C. 
National War Labor Board

William H. Davis, Chairman

Department of Labor Building

I 4 th \& Constitution

Ship Stabilization Committee

Paul R. Porter, Chairman

Social Security Building

Fourth Street and Independence Avenue, S. W.

United States Conciliation Service

John R. Steelman, Director

U. S. Department of Labor

I $4^{\text {th }} \&$ Constitution

War Manpower Commission

Paul V. McNutt, Chairman

Social Security Building

Fourth Street and Independence Avenue, S. W. 